\title{
Bioidentical Hormones for Menopausal Hormone Therapy: Variation on a Theme
}

\author{
Adriane Fugh-Berman, MD and Jenna Bythrow, MS candidate \\ Complementary and Alternative Medicine Master's Program, Department of Physiology and Biophysics, Georgetown University School of \\ Medicine, 571460, Washington, DC 20052-1460, USA.
}

\begin{abstract}
BACKGROUND: Progesterone creams and natural or bioidentical compounded estrogen preparations are being promoted to consumers as safe alternatives to conventional menopausal hormone therapy and as healthpromoting tonics. No reliable data support these claims.
\end{abstract}

SAFETY: Natural hormones, including estradiol, estriol, estrone, and progesterone, can be expected to have the same adverse event profile as conventional menopausal hormone regimens.

SALIVARY HORMONE TESTS: Salivary tests may be used to persuade asymptomatic consumers to use hormones (or symptomatic patients to use higher doses than those needed to mitigate symptoms), a practice that can be expected to result in adverse events.

KEY WORDS: natural hormones; bioidentical hormones; menopausal hormone therapy; topical progesterone cream; estriol; compounding pharmacies; Triest; salivary hormone testing.

DOI: $10.1007 / \mathrm{s} 11606-007-0141-4$

(C) 2007 Society of General Internal Medicine 2007;22:1030-1034

$\mathrm{B}$ ioidentical or natural hormones are being promoted to consumers as benign health tonics. The term bioidentical is a pseudoscientific neologism that refers to endogenous hormones, including estriol, estrone, estradiol, progesterone, testosterone, DHEA, thyroxine, and cortisol. Natural alludes to the fact that these are native human hormones. In fact, these hormones are synthesized or semisynthesized. Stigmasterol from soybeans (Glycine max) and diosgenin from an inedible Mexican yam (Dioscorea villosa) can be converted to progesterone in the laboratory, ${ }^{1}$ but there is no evidence that plant sterols convert to progesterone endogenously.

Many bioidentical hormone products that require a prescription are prepared by compounding pharmacies. Compounding pharmacies use commercially available drugs to create formulations that are not commercially available. For example, compounding pharmacies routinely turn tablets into syrup for patients with swallowing problems, combine two or three pills into a single capsule, make a pet-sized dose of a drug meant for humans, or make a topical preparation from a

Received June 24, 2006

Revised September 27, 2006

Accepted December 21, 2006

Published online March 7, 2007 drug available only in an oral form. Because compounding pharmacies are not manufacturing facilities, they are not subject to FDA standards for good manufacturing practices. Compounded preparations are not regulated by the FDA and may vary in potency. For example, one study found that only 1 of 10 compounding pharmacies provided progesterone vaginal suppositories that were all within the potency range required of similar FDA-approved products. ${ }^{2}$

This article will focus on compounded bioidentical hormone preparations aimed at menopausal and perimenopausal women. Oral products include estriol, biestrogen (Bi-est, containing $20 \%$ estradiol and $80 \%$ estriol), or triestrogen (Tri-est, containing $10 \%$ estrone, $10 \%$ estradiol, and $80 \%$ estriol). Estriol is usually dosed at $2 \mathrm{mg}$ twice daily; the usual dose of Bi-est or Triest is $1.25-2.5 \mathrm{mg}$ twice daily. These doses are believed to be equivalent to $0.625-1.25 \mathrm{mg}$ of conjugated equine estrogens. The term estrogens encompasses all forms, including human estrogens (estradiol, estriol, and estrone), synthetic forms (for example, ethinyl estradiol), and conjugated equine estrogens (mixed estrogens derived from mare's urine). The term progestogen is an umbrella term that encompasses progesterone, which is the mammalian progestogen, and synthetic progestins (for example, medroxyprogesterone). Bioidentical progesterone is micronized progesterone, oral forms of which are used in conventional medicine. Transdermal progesterone cream, however, remains an alternative treatment in the United States.

Although all oral hormonal preparations require a prescription, topical hormone preparations are generally regulated as cosmetics, not drugs, ${ }^{3}$ and so are readily available without a prescription. Health food stores sell progesterone and DHEA creams, and estrogen creams may be purchased on the internet.

\section{HEALTH CLAIMS}

Estrogen is an effective treatment for hot flashes and vaginal dryness, but neither estrogen nor estrogen/progestin therapy should be used for disease prevention. Natural hormone proponents, however, claim that bioidentical hormones are different than conventional hormone regimens and will prevent disease. An educational packet distributed by one compounding pharmacy claims that "there are cardiovascular benefits to hormone therapy...protecting against premature heart disease, hypertension, and cholesterol." ${ }^{4}$ Another pharmacy states that their hormone therapy protects against heart disease, breast cancer, and endometrial cancer. ${ }^{5}$ A company that sells various hormones over the internet describes estrogen as "literally a heart saver." And another pharmacy states that Bi-est "... 
might allow for all of the protection of estriol, while potentially providing the cardiovascular and osteoporosis benefits and vasomotor symptom relief of estradiol." 7

Although estrogen or estrogen-progestogen combinations are far more common, oral or injected progestogens are occasionally used in conventional medicine to treat hot flashes.

Transdermal progesterone cream has also been tested for hot flashes; one study found a positive effect ${ }^{8}$ and another found no effect. ${ }^{9}$ Progesterone cream is promoted to treat and prevent osteoporosis, and as a general health tonic. However, no clinical trials support the use of progesterone cream for either of these claims.

The perception that progesterone cream is a panacea can be traced to the late John M. Lee, MD, whose popular books claimed that breast cancer, fibroids, fibrocystic breasts, premenstrual syndrome, osteoporosis, and other conditions were all linked to "estrogen dominance secondary to relative insufficiency of progesterone." ${ }^{10-13}$ One web site that sells progesterone cream states that "Natural progesterone cream contains NO synthetic hormones and thus can help you balance your hormones, eliminate estrogen dominance and relieve your symptoms without dangerous side effects." ${ }^{14}$ Another web site claims, "Natural progesterone should not be confused with the progestins or progestogens in birth control pills and other drugs... Natural, USP progesterone, on the other hand, is identical to the body's own progesterone molecule, and has no serious side effects when used as directed." ${ }^{15}$

Popular books have contributed to misconceptions about hormones. Actress Suzanne Somers has published three books promoting bioidentical hormone therapy in 3 years. In her latest book, Ageless: the Naked Truth About Bioidentical Hormones, Somers states, "Hormones are our life force; the decline of hormones is the hallmark of aging;" "Without hormone replacement, we will end up mere shells of our former selves;" and "Disease doesn't develop when hormones are in perfect balance." ${ }^{16}$ Despite developing breast cancer and undergoing a hysterectomy for endometrial hyperplasia while taking bioidentical hormones, Somers remains a hormone enthusiast.

Several physicians promote these hormones. Erica Schwartz, MD, author of The Hormone Solution: Naturally Alleviate Symptoms of Hormone Imbalance from Adolescence Through Menopause (NY: Warner Books; 2002) and The 30-Day Natural Hormone Plan: Look and Feel Young Again-Without Synthetic HRT (NY: Warner Books; 2004) evaluates patients through telephone interviews and prescribes hormone treatment. Schwartz states on her web site, "Natural' Bio Identical Hormones are exactly the same as the hormones your body made when you were younger except they don't have the same adverse side effects commonly associated with 'Synthetic' Hormone Replacement Therapy. "17

Steven F. Hotze, MD, author of Hormones, Health, and Happiness (Houston, Tex, USA: Forrest Publishers; 2005) and proprietor of the Hotze Health and Wellness Center in Houston, Tex, USA claims that, "When our hormones are in balance we are young, healthy, radiant, fertile, wrinkle free and excited about the posibilities life can offer." 18

\section{SAFETY}

The terms bioidentical and natural may imply safety to consumers. A survey of 82 women interviewed at a compounding pharmacy found that 74 had heard about natural hormones and 37 used them. ${ }^{19}$ Half of those who had heard about natural hormones believed that natural meant "not synthetic/not man-made/no chemicals" and 45\% thought the term meant plant-derived. Only $11 \%$ agreed that natural meant "identical to human hormones." More than two thirds (71.4\%) of respondents believed that natural hormones had fewer risks than pharmaceutical hormones.

Bioidentical hormones are identical to hormones used in some commercial pharmaceutical preparations. Estradiol, for example, is available in pills (including Estrace ${ }^{\circledR}$, Gynodiol ${ }^{\circledR}$, and generics), transdermal delivery systems $\left(\right.$ Climara $^{\circledR}$, Alora $^{\circledR}$, Estraderm $^{\circledR}$, Vivelle ${ }^{\circledR}$, and generics), vaginal creams (Estrace ${ }^{\circledR}$ and generics), and vaginal rings (Estring $\left.{ }^{(}\right)$and Femring $\left.{ }^{(}\right)$. Progesterone is available in capsules (Prometrium ${ }^{\circledR}$, Solvay Pharmaceuticals, Marietta, Ga, USA [marketed], manufacturer: Schering Plough) and vaginal gels (Crinone ${ }^{\circledR}$, Serono Laboratories, Inc., Rockland, Mass, USA and Prochieve, Columbia Laboratories, Livingston, NJ, USA). Ironically, the estrogen in the best-selling hormone preparations Premarin ${ }^{\circledR}$, PremPro ${ }^{\circledR}$, and Premphase ${ }^{\circledR}$ (Wyeth, Philadelphia, Pa, USA) is derived from pregnant mare's urine, an inarguably natural source.

Interest in bioidentical hormones appears to have increased since 2002, when the estrogen-progestin arm of the NIH-funded Women's Health Initiative (WHI) was stopped because of harm. ${ }^{20}$ (the estrogen-only arm was stopped in 2004). In this definitive randomized controlled trial (RCT) that included more than 26,000 women, neither estrogen ${ }^{21}$ nor estrogen-progestin combinations reduced cardiovascular risk. ${ }^{20,22,23}$ Both estrogen ${ }^{24}$ and estrogen-progestin therapy ${ }^{25}$ increased stroke risk; estrogenprogestin therapy increased rates of breast cancer ${ }^{20}$ and dementia. ${ }^{26,27}$ Hormone therapy increased the risk of incontinence ${ }^{28}$ and improved quality of life only in women with hot flashes. ${ }^{29}$

The WHI tested conjugated equine estrogens (with and without medroxyprogesterone acetate), but no RCT to date has shown a benefit for any estrogen on cardiovascular events. Two RCTs have shown that estradiol, a natural hormone, prevents neither heart attack ${ }^{22,23}$ nor stroke. ${ }^{30}$

Estriol, specifically, is believed by bioidentical hormone proponents to decrease breast cancer risk. This belief is based on several articles written in the 1970s by a researcher who remained enthusiastic about estriol even after his only published clinical study failed. Six of the 24 subjects with breast cancer who took estriol developed metastases; two developed endometrial hyperplasia. ${ }^{31}$ The researcher, however, never made specific disease prevention claims about estriol.

Other evidence refutes the purported benignity of bioidentical estrogens on the breast. High levels of endogenous estradiol and estrone are associated with increased breast cancer risk; ${ }^{32-37}$ estriol has also been implicated in increased risk. ${ }^{38}$ In breast cancer cell lines, estriol stimulates breast cancer cell growth more than other estrogens. ${ }^{39}$ Breast tissue from women with breast cancer, compared to women without breast cancer, contains higher levels of estriol, estrone, and estradiol. ${ }^{40}$

Little information is available about long-term effects of micronized progesterone. There is preliminary evidence from E3N-EPIC, a large French cohort study of 98,997 women followed up for a mean of 5.8 years, that hormone regimens incorporating micronized progesterone rather than other progestogens may be safer in terms of breast cancer risk. ${ }^{41}$ However, this is an observational study, not an RCT, that included hormone regimens rarely used in other countries. This study by no means constitutes proof of a differential effect. 


\section{ENDOMETRIAL EFFECTS OF TRANSDERMAL PROGESTERONE CREAMS AND ESTRIOL}

Women with intact uteri are prescribed estrogen with a progestogen to oppose estrogen-induced endometrial hyperplasia and cancer. Bioidentical hormone proponents sometimes recommend topical progesterone cream instead of oral progestin for this purpose. However, it is unclear whether topical progesterone can effectively mitigate estrogen-induced endometrial stimulation. Three studies have examined the ability of progesterone to oppose estrogenic stimulation. The longest study, which lasted for 48 weeks, found that transdermal cream containing $40 \mathrm{mg}$ of progesterone could not effectively oppose estradiol-induced endometrial stimulation. ${ }^{42}$ A 12-week study of a cream containing up to $64 \mathrm{mg}$ of progesterone found similar effects. ${ }^{43}$ The only study that found that progesterone cream ( $1.5 \%$ or $4 \%$, dosed by body weight) effectively opposed estrogen lasted only 28 days, too short a time to assess estrogenic effects. ${ }^{44}$ Five studies that measured serum or plasma levels after topical progesterone treatment have found progesterone levels $<5 \mathrm{ng} / \mathrm{mL}$ (the minimum level believed to induce a secretory endometrium). ${ }^{45-49}$ Only one study found a progesterone cream equivalent to oral progesterone after measuring progesterone concentration in whole blood $^{50}$ (Table 1).

Although oral estriol preparations are an alternative treatment for menopausal symptoms in the United States, estriol is a commonly prescribed conventional drug in other countries ${ }^{51}$ and was often prescribed without a progestin. Although estriol is far less potent than estradiol and rapidly metabolized, estriol appears to stimulate proliferative changes identical to those induced by more potent estrogens. ${ }^{52}$ Two Swedish studies

Table 1. Bioavailability Studies on Topical Progesterone Cream

\begin{tabular}{|c|c|c|c|}
\hline Author & Subjects & Design & Preparations \\
\hline $\begin{array}{l}\text { Leonetti } \\
\text { et al. }{ }^{44}\end{array}$ & $\begin{array}{l}37 \text { postmenopausal } \\
\text { women ( } 32 \\
\text { analyzed) }\end{array}$ & $\begin{array}{l}\text { Randomized, } \\
\text { placebo- } \\
\text { controlled } \\
\text { trial (28 d) }\end{array}$ & $\begin{array}{l}\text { Progesterone cream ( } 1.5 \% \text { or } 4.0 \% \text {, dosed } \\
\text { by weight) } \\
\text { Placebo cream, each applied } \\
\text { topically twice daily } \\
\text { All subjects received conjugated } \\
\text { estrogens ( } 0.625 \mathrm{mg} / \mathrm{d} \text {, starting } 2 \mathrm{wks} \\
\text { before progesterone) }\end{array}$ \\
\hline $\begin{array}{l}\text { Wren } \\
\text { et al. }^{8}\end{array}$ & $\begin{array}{l}27 \text { postmenopausal } \\
\text { women ( } 23 \\
\text { completed) }\end{array}$ & $\begin{array}{l}\text { Randomized } \\
\text { crossover } \\
\text { study } \\
\text { (12 wks) }\end{array}$ & $\begin{array}{l}\text { ProFemme cream (containing } 16,32 \text {, or } \\
64 \mathrm{mg} \text { micronized progesterone), each for } \\
\text { latter } 2 \text { wks of each } 4 \text {-wk treatment cycle } \\
7 \beta \text {-estradiol patch worn throughout } \\
\text { study }\end{array}$ \\
\hline $\begin{array}{l}\text { Vashisht } \\
\text { et al. }^{42,59}\end{array}$ & $\begin{array}{l}54 \text { menopausal } \\
\text { women ( } 41 \\
\text { completed) }\end{array}$ & $\begin{array}{l}\text { Open-label } \\
\text { study } \\
\text { (48 wks) }\end{array}$ & $\begin{array}{l}\text { Progestelle }(6 \% \text { progesterone cream } \\
\text { containing } 40 \mathrm{mg} \text { progesterone/d) } \\
\text { Topical estradiol gel }(1 \mathrm{mg} / \mathrm{d}) \text { throughout } \\
\text { study }\end{array}$ \\
\hline
\end{tabular}

$\begin{array}{cccc}\begin{array}{c}\text { Hermann } \\ \text { et al. }\end{array} & \begin{array}{c}12 \text { postmenopausal } \\ \text { women }\end{array} & \begin{array}{c}\text { Randomized } \\ \text { controlled } \\ \text { crossover }\end{array} & \begin{array}{c}\text { Pro-Gest cream (40 mg twice daily) } \\ \text { Prometrium (micronized progesterone, }\end{array} \\ & & 200 \text { mg orally daily, each for } 12 \mathrm{~d} \text { ) }\end{array}$

$\begin{array}{cc}\text { Lewis } & \begin{array}{c}\text { Postmenopausal } \\ \text { et al. }\end{array} \\ & \begin{array}{c}\text { women (22 } \\ \text { completed) }\end{array}\end{array}$

$\begin{array}{ccc}\begin{array}{c}\text { Carey } \\ \text { et al. }\end{array} & \begin{array}{c}\text { 24 postmenopausal } \\ \text { women (19 } \\ \text { completed) }\end{array} & \begin{array}{c}\text { Open-label } \\ \text { study (42 }\end{array} \\ \begin{array}{c}\text { O'Leary } \\ 2000\end{array} & \begin{array}{c}12 \text { women } \\ \text { (6 postmenopausal, }\end{array} & \begin{array}{c}\text { Open-label } \\ \text { study } \\ \text { et al. }\end{array} \\ \begin{array}{c}\text { (single } \\ \text { Burry }\end{array} & \begin{array}{c}6 \text { premenopausal) } \\ \text { et al. }\end{array} & \begin{array}{c}\text { (s8 } \\ \text { dose) }\end{array} \\ & \text { women } & \begin{array}{c}\text { Open-label } \\ \text { study } \\ \text { (4 wks) }\end{array}\end{array}$

$\begin{array}{cc}\text { Cooper } & 20 \text { surgically } \\ \text { et al. } & \text { menopausal } \\ & \text { women }\end{array}$

Randomized, Compounded progesterone cream double- $\quad 20 \mathrm{mg} / \mathrm{g} 1-2 \mathrm{~g}$

blind, Compounded progesterone cream placebo- $\quad(40 \mathrm{mg} / \mathrm{g}) 1-2 \mathrm{~g}$

controlled Placebo (treatments applied twice daily for trial ( $8 \mathrm{wks}) \quad 3 \mathrm{wks}$ each, with a 1 -wk washout) Open-label Progestelle cream (containing $40 \mathrm{mg}$ Progestelle cream (containin
progesterone once daily) Progestelle cream (containing $20 \mathrm{mg}$ progesterone twice daily)

ProFemme cream (containing $64 \mathrm{mg}$ progesterone)

Pro-Gest cream (containing $30 \mathrm{mg}$ progesterone daily) $\times 2 \mathrm{wks}$, then $30 \mathrm{mg}$ wice daily $\times 2$ wks

Transdermal estradiol patch $0.05 \mathrm{mg}$ worn throughout study

Randomized One teaspoon of Pro-Gest cream or controlled crossover study (33 d) placebo (each treatment applied twicedaily $\times 10 \mathrm{~d}$, with a 4 -d washout period) Each subject then took Uterogestan (oral
Results

Endometrial biopsies showed significant decrease in endometrial proliferation scores in both treatment groups, compared with placebo and compared to baseline biopsies taken 2 wks after estrogen treatment.

None of the 21 endometrial biopsies obtained indicated a secretory endometrium. Serum progesterone levels rose to $0.6-3.2 \mathrm{ng} / \mathrm{mL}$.

Endometrial biopsies showed that mean endometrial thickness increased significantly from 3.3 to $5.5 \mathrm{~mm}$. At $48 \mathrm{wks}$, out of 39 biopsies obtained, 2 showed endometrial hyperplasia, and 10 demonstrated endometrial proliferation. Median plasma progesterone levels increased from 1.9 to $2.5 \mathrm{nmol} / \mathrm{L}$. In a whole blood assay, progesterone levels increased after both topical and oral progesterone. No significant difference between groups; median AUC (area under the curve) was $12.5 \mathrm{ng} \mathrm{h}^{-1} \mathrm{~mL}^{-1}$ after Pro-Gest and

$10.5 \mathrm{ng} \mathrm{h}^{-1} \mathrm{~mL}^{-1}$ after oral progesterone.

Plasma progesterone increased significantly but slightly in both treated groups, compared to the placebo group (range $0.32-1.77 \mathrm{nmol} / \mathrm{L}$ in the 20-mg group, $0.59-3.53 \mathrm{nmol} / \mathrm{L}$ in the $40-\mathrm{mg}$ group). Salivary progesterone levels were high, variable, and did not correlate with serum levels. Serum progesterone increased to $2.5-3.0 \mathrm{nmol} / \mathrm{L}$ (with wide variation). No difference between single and divided dose.

No change from baseline in serum progesterone in either group $3 \mathrm{~h}$ after treatment. Salivary progesterone rose significantly in both groups within an hour.

Mean serum progesterone levels rose to $1.0-3.3$ $\mathrm{ng} / \mathrm{mL}$. progesterone $100 \mathrm{mg}$ qam and $200 \mathrm{mg}$ qpm $\times 5 \mathrm{~d}$ 
found that unopposed oral estriol (1-2 mg/day) was associated with endometrial hyperplasia. ${ }^{53,54}$ Compared to nonusers, the use of oral estriol doubled the risk of endometrial cancer; 5 years of oral estriol tripled the risk. Vaginal estriol did not significantly increase risk. ${ }^{54}$ Although one recent study concluded that estriol has a benign effect on the endometrium, ${ }^{55}$ the data presented show that estriol treatment was associated with significant endometrial thickening and polyps, both considered to be estrogenic effects. ${ }^{56}$

The FDA's Guidance for Industry states, "other combinations and dosage forms of estrogens and progestins were not studied in the WHI clinical trials and, in the absence of comparable data, these risks should be assumed to be similar."

\section{SALIVARY HORMONE TESTS}

Saliva testing for hormones has been promoted to individualize the dosing of bioidentical hormone treatment. It is not clear how best to correlate progesterone levels with endometrial effects, but it is clear that salivary progesterone levels are unreliable. Correlations between serum and salivary levels of reproductive hormones vary by hormone tested, time of day, diet, and type of assay. ${ }^{51}$ Also, serum levels may not reflect tissue levels. ${ }^{58}$

Hormone tests are not indicated for menopausal symptoms because there is no correlation between hormone levels and symptoms. Salivary tests may be used to persuade asymptomatic women to use hormones, and may encourage symptomatic women to use higher doses than are necessary to treat symptoms. This would be expected to result in an unfavorable risk-benefit ratio. As Boothby et al. ${ }^{51}$ stated in an excellent review, "Although attractive on the surface, individualized NHT [natural hormone therapy] is an ill-conceived attempt to apply pharmacokinetic principles to drugs that do not meet the criteria for individualized dosing."

\section{DISCUSSION}

Bioidentical hormones are an unusual form of alternative medicine. Unlike dietary supplements, most orally administered hormones require a physician's prescription. Despite the fact that these hormones are no more natural than (and in many cases are identical to) commercially available drugs, when formulated by a compounding pharmacy these preparations fall outside of the current realm of FDA regulation. No reliable data support the claim that bioidentical hormones are safer than other hormones, and natural, bioidentical, and compounded preparations must be assumed to have the same risks as commercial hormone preparations.

Commercial or compounded estrogen preparations should be effective for treating hot flashes or vaginal dryness, and oral micronized progesterone is acceptable as the progestogen portion of menopausal hormone therapy. Any estrogen, including estriol, should be opposed with an oral progestogen in nonhysterectomized women. Whereas some progesterone creams may provide some endometrial protection in some women, studies to date are not reassuring. Progesterone creams should not be relied upon to protect uterine endometrium from estrogen-induced stimulation. Oral progestogens with known effects are preferred.

Any menopausal hormone therapy should be reserved for women with bothersome symptoms, and used in the lowest effective dose for as brief a period as possible. Whereas compounded preparations may be useful for creating lowerdose preparations of hormones, these preparations lack the consistency and regulatory oversight required of commercial hormonal drugs.

Adverse effects of hormones must be assumed to be drug class effects until reliable clinical evidence proves otherwise. Claims that the hormones present in compounded prescriptions are safer than commercial pharmaceuticals can only be made by those unfamiliar with or unwilling to accept scientific data. Women who wish to use compounded hormones to treat menopausal symptoms should be counseled that bioidentical hormones have the same risks as conventional hormones.

Because hormones are readily absorbed through the skin, the FDA should regulate transdermal hormone preparations as drugs. In addition, the FDA should require compounding pharmacies to provide patients with the same written information required of commercial drugs with any compounded prescriptions made with those drugs. To do otherwise risks the health of consumers.

Acknowledgement: This work was partially supported by a grant from the Attorney General Prescriber and Consumer Education Grant Program. The authors received no funding for this report.

Conflict of Interest: Dr. Fugh-Berman has provided expert testimony on the plaintiff's side in litigation regarding Prempro ${ }^{\circledR}$ (Wyeth). $J$. Bythrow is currently employed as a pharmaceutical sales representative with Eli Lilly.

Corresponding Author: Adriane Fugh-Berman, MD; Complementary and Alternative Medicine Master's Program, Department of Physiology and Biophysics, Georgetown University School of Medicine, 571460, Washington, DC 20052-1460, USA (e-mail: aif29@ georgetown.edu).

\section{REFERENCES}

1. Hogg JA. Steroids, the steroid community, and Upjohn in perspective: a profile of innovation. Steroids. 1002;57:593-616.

2. Mahaguna V, McDermott JM, Zhang F, Ochoa F. Investigation of product quality between extemporaneously compounded progesterone vaginal suppositories and an approved progesterone vaginal gel. Drug Dev Ind Pharm. 2004;30(10):1069-78.

3. Food and Drug Administration. Available via the internet at http://www. cfsan.fda.gov/ dms/cfsand04.html. Accessed 19 Sep 2006.

4. Women's International Pharmacy. Especially Designed for Women. Youngtown, Ariz, and Madison, Wisc., USA: Women's International Pharmacy; 8-9 April 2002.

5. Premier Pharmacy. Available at http://premier-pharmacy.com/ abouthrt3.html. Accessed Jul 2005. (PDF no longer available)

6. MedXLife. Available at http://medxlife.com/getArticles.asp?aId=54\& categoryId=10. Accessed 5 Nov 2004.

7. College Pharmacy. Available at http://www.collegepharmacy.com/ specializations/biest.asp. Accessed Jul 2005.

8. Wren BG, Champion SM, Willetts K, Manga RZ, Eden JA. Transdermal progesterone and its effect on vasomotor symptoms, blood lipid levels, bone metabolic markers, moods, and quality of life for postmenopausal women. Menopause. 2003;10(1):13-8.

9. Leonetti HB, Longo S, Anasti JN. Transdermal progesterone cream for vasomotor symptoms and postmenopausal bone loss. Obstet Gynecol. 1999;94:225-8.

10. Lee J. Natural Progesterone: The Multiple Roles of a Remarkable Hormone. Sebastopol, Calif: BLL Publishing; 1993.

11. Lee JR, Zava D, Hopkins V. What Your Doctor May Not Tell You About Breast Cancer! How Hormone Balance Can Help Save Your Life. New York, NY: Warner Books; 2002. 
12. Lee JR, Hanley J, Hopkins V. What Your Doctor May Not Tell You About Premenopause: Balance Your Hormones and Your Life from Thirty to Fifty. New York, NY: Warner Books; 1999.

13. Lee JR, Hopkins V. What Your Doctor May Not Tell You About Menopause: The Breakthrough Book on Natural Progesterone. New York, NY: Warner Books; 2004.

14. AltMedNetwork. Available at http://www.altmednetwork.net/whealth/ progest_crm.html. Accessed Jun 2005.

15. Pure Essence Labs. Available at http://www.pureessencelabs.com/pdf/ femcreme.pdf. Accessed Jun 2005. (PDF no longer available)

16. Sommers S. Ageless: the naked truth about bioidentical hormones. New York, NY: Crown Publishers; 2006:7, 23, 71.0.

17. DrErika.com. Available at http://drerika.com/EN/index.html. Accessed 31 Oct 2005

18. Hotze S. Hormones and the woman's life cycles. Available at http:// www.drhotze.com/EN/online_articles/389.html. Accessed Feb 2007

19. Adams C, Cannell S. Women's beliefs about "natural" hormones and natural hormone replacement therapy. Menopause. 2001;8(6):433-40.

20. Writing group for the Women's Health Initiative investigators. Risks and benefits of estrogen plus progestin in healthy postmenopausal women: principal results from the Women's Health Initiative randomized controlled trial. JAMA. 2002;288(3):321-33.

21. Anderson GL, Limacher M, Assaf AR, et al., Women's Health Initiative Steering Committee. Effects of conjugated equine estrogen in postmenopausal women with hysterectomy: the Women's Health Initiative randomized controlled trial. JAMA. 2004;291(14):1701-12.

22. Cherry N, Gilmour $\mathbf{K}$, Hannaford P, et al., ESPRIT team. Oestrogen therapy for prevention of reinfarction in postmenopausal women: a randomised placebo controlled trial. Lancet. 2002;360(9350):2001-8.

23. ESPRIT. Oestrogen therapy for prevention of reinfarction in postmenopausal women: a randomized placebo controlled trial. Lancet. 2002;360:2001-8.

24. Hendrix SL, Wassertheil-Smoller S, Johnson KC, et al.,WHI Investigators. Effects of conjugated equine estrogen on stroke in the Women's Health Initiative. Circulation. 2006;113(20):2425-34.

25. Wassertheil-Smoller S, Hendrix SL, Limacher M, et al., WHI Investigators. Effect of estrogen plus progestin on stroke in postmenopausal women: the Women's Health Initiative: a randomized trial. JAMA. 2003;289(20):2673-84

26. Shumaker SA, Legault C, Rapp SR, et al., WHIMS Investigators. Estrogen plus progestin and the incidence of dementia and mild cognitive impairment in postmenopausal women: the Women's Health Initiative Memory Study: a randomized controlled trial. JAMA. 2003;289(20):2651-62.

27. Shumaker SA, Legault C, Kuller L, et al., Women's Health Initiative Memory Study. Conjugated equine estrogens and incidence of probable dementia and mild cognitive impairment in postmenopausal women: Women's Health Initiative Memory Study. JAMA. 2004;291(24):2947-58.

28. Hendrix SL, Cochrane BB, Nygaard IE, et al. Effects of estrogen with and without progestin on urinary incontinence. JAMA. 2005;293(8):935-48.

29. Hays J, Ockene JK, Brunner RL, et al. Effects of estrogen plus progestin on health-related quality of life. N Engl J Med. 2003;348(19):1839-54.

30. Viscoli CM, Brass LM, Kernan WN, Sarrel PM, Suissa S, Horwitz RI. A clinical trial of estrogen-replacement therapy after ischemic stroke. N Engl J Med. 2001;345(17):1243-9

31. Lemon HM. Pathophysiologic considerations in the treatment of menopausal patients with oestrogens; the role of oestriol in the prevention of mammary carcinoma. Acta Endocrinol Suppl (Copenh). 1980;233:1727.

32. Endogenous Hormones and Breast Cancer Collaborative Group. Endogenous sex hormones and breast cancer in postmenopausal women: reanalysis of nine prospective studies. J Natl Cancer Inst. 2002;94 (8):606-16.

33. Zeleniuch-Jacquotte A, Shore RE, Koenig KL, et al. Postmenopausal levels of oestrogen, androgen, and SHBG and breast cancer: long-term results of a prospective study. Br J Cancer. 2004;90(1):153-9.

34. Manjer J, Johansson R, Berglund G, et al. Postmenopausal breast cancer risk in relation to sex steroid hormones, prolactin and SHBG (Sweden). Cancer Causes Control. 2003;14(7):599-607.

35. Key TJ, Appleby PN, Reeves GK, et al., Endogenous Hormones Breast Cancer Collaborative Group. Body mass index, serum sex hormones, and breast cancer risk in postmenopausal women. J Natl Cancer Inst. 2003;95(16): 1218-26.

36. Onland-Moret NC, Kaaks R, van Noord PA, et al. Urinary endogenous sex hormone levels and the risk of postmenopausal breast cancer. $\mathrm{Br} \mathrm{J}$ Cancer. 2003;88(9):1394-9.
37. Yu H, Shu Xo, Shi R, et al. Plasma sex steroid hormones and breast cancer risk in Chinese women. Int J Cancer. 2003;105(1):92-7.

38. Hankinson SE, Willett WC, Manson JE, et al. Plasma sex steroid hormone levels and risk of breast cancer in postmenopausal women. J Natl Cancer Inst. 1998;90:1292-1299.

39. Lippert C, Seeger H, Mueck AO. The effect of endogenous estradiol metabolites on the proliferation of human breast cancer cells. Life Sci. 2003;72(8):877-83.

40. Mady EA, Ramadan EE, Ossman AA. Sex steroid hormones in serum and tissue of benign and malignant breast tumor patients. Dis Markers. 2000;16(3-4):151-7.

41. Fournier A, Berrino F, Riboli E, Avenel v, Clavel-Chapelon F. Breast cancer risk in relation to different types of hormone replacement therapy in the E3N-EPIC cohort. Int J Cancer. 2005; 114(3):448-54.

42. Vashisht A, Wadsworth F, Carey A, Carey B, Studd J. A study to look a hormonal absorption of progesterone cream used in conjunction with transdermal estrogen. Gynecol Endocrinol. 2005;21(2):101-5.

43. Wren, B. G., McFarland, K., Edwards, L. Micronised transdermal progesterone and endometrial response. Lancet 1999;354:1447-8.

44. Leonetti HB, Wilson KJ, Anasti JN. Topical progesterone cream has an antiproliferative effect on estrogen-stimulated endometrium. Fertil Steril. 2003;79(1):221-2 (Jan)

45. Lewis JG, McGill H, Patton VM, Elder PA. Caution on the use of saliva measurements to monitor absorption of progesterone from transdermal creams in postmenopausal women. Maturitas. 2002;41:1-6.

46. Carey BJ, Carey AH, Patel S, Carter G, Studd JW. A study to evaluate serum and urinary hormone levels following short and long term administration of two regimens of progesterone cream in postmenopausal women. BJOG. 2000;107(6):722-6.

47. O'Leary PO, Feddema P, Chan K, et al. Salivary, but not serum or urinary levels of progesterone are elevated after topical application of progesterone cream to pre- and postmenopausal women. Clin Endocrinol. 2000;53:615-20.

48. Burry KA, Patton PE, Hermsmeyer K. Percutaneous absorption of progesterone in postmenopausal women treated with transdermal estrogen. Am J Obstet Gynecol. 1999;180(6 Pt 1):1504-11.

49. Cooper A, Spencer C, Whitehead MI, Ross D, Barnard GJ, Collins WP. Systemic absorption of progesterone from Progest cream in postmenopausal women. Lancet. 1998;351(9111):1255-6.

50. Hermann AC, Nafziger AN, Victory J, Kulaway R, Rocci ML, Bertino JS. Over-the-counter progesterone cream produces significant drug exposure compared to a Food and Drug Administration approved oral progesterone. J Clin Pharmacol. 2005;45:614-9.

51. Boothby LA, Doering PL, Kipersztok S. Bioidentical hormone therapy: a review. Menopause. 2004;11(3):356-67.

52. van Haaften M, Donker GH, Sie-Go DM, Haspels AA, Thijssen JH Biochemical and histological effects of vaginal estriol and estradio applications on the endometrium, myometrium and vagina of postmenopausal women. Gynecol Endocrinol. 1997;11(3):175-85.

53. Granberg S, Ylostalo P, Wikland M, Karlsson B. Endometrial sonography and histological findings in women with and without hormonal replacement therapy suffering from post menopausal bleeding. Maturitas. 1997;27:35-40.

54. Weiderpass E, Baron JA, Adami H-O, et al. Low-potency oestrogen and risk of endometrial cancer: a case-control study. Lancet. 1999;353: 1824-8.

55. Granberg S, et al. The effects of oral estriol on the endometrium in postmenopausaul women. Maturitas. 2002;42:149-56.

56. Scialli A, Fugh-Berman A. The effects of oral estriol on the endometrium in postmenopausal women. Maturitas. 2003;45(2):147; author reply 149.

57. Food and Drug Administration. Food and Drug Administration Labeling Guidance for Noncontraceptive Estrogen Drug Products for the Treatment of Vasomotor Symptoms and Vulvar and Vaginal Atrophy Symptoms-Prescribing Information for Health Care Providers and Patient Labeling, revision 1. USA: Center for Drug Evaluation and Research (CDER), revision 1. Available at http://www.fda.gov/cder/guidance/ index.htm; February 2004.

58. Stanczyk FZ, Paulson RJ, Roy S. Percutaneous administration of progesterone: blood levels and endometrial protection. Menopause. $2005 ; 12(2): 232-7$

59. Vashisht A, Wadsworth F, Carey A, Carey B, Studd J. Bleeding profiles and effects on the endometrium for women using a novel combination of transdermal oestradiol and natural progesterone cream as part of a continuous combined hormone replacement regime. BJOG. 2005;112 (10): 1402-6 